\title{
A REVIEW: A FRAMEWORK FOR YIELD IMPROVEMENT IN KHARIF/RAINY SEASON POTATO IN THE LOW LAND TROPICS
}

\author{
Shankar RAJA*, Govindakrishnan PM, Chakrabarti SK \\ ICAR-Central Potato Research Institute-Shimla, India
}

\begin{abstract}
Potato is a temperate crop greately adapted to tropical climate as evidenced by the greater share of production by the tropical countries in recent years. It is grown mainly during rainy seasons coupled with long summers in majority of potato growing countries. However, the sub-tropics country like India, kharif (or) rainy season potatoes is still an underexploited segment which is mainly restricted to hills and plateaus, but not plains. Unlike short day crops grown during winter, the yield of kharif potato is far lower. However, the simulation model estimated the attainable yield could be enhanced substantially by extending canopy cover (100\%) duration from 10 to and 40 days over the existing window of favourable growing period at various kharif growing

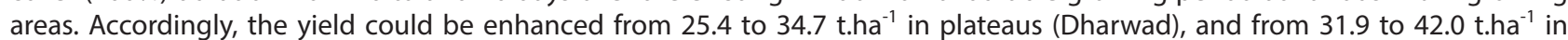
Northern HH (Shimla). The South and Northern HH locations (Ooty and Shimla respectively) registered a higher attainable yield (45.1 and 42.0 t.ha $^{-1}$, respectively) which strongly indicates the necessity of trait specific improvement program for developing better phenotype combination having high water, radiation and light use efficiency for enhanced yield potential.
\end{abstract}

Keywords: environment, future research, genotype, kharif potato, physiological breeding

Potato (Solanum tuberosum L.) is considered to be the $3^{\text {rd }}$ most important food crop in the world. It is grown in $>125$ countries comprising $52 \%$ areas located in temperate region in Europe, $34 \%$ in Asia and 14\% in Africa. The world potato production is estimated at 364.8 million $t$ in 2012 (FAO, 2014), where the production share of the developing world exceeded the developed (Scott and Suarez, 2011. Potato is grown in majority of leading potato growing countries during rainy seasons under long summer which results in higher productivity (Table 1). India is the $2^{\text {nd }}$ largest producer of potato in the world (Scott and Suarez, 2011) by producing 45.34 million t from 1.99 million ha (22.8 t.ha ${ }^{-1}$ ) during 2012-2013 (NHB, 2013). Kharif crop is grown during rainy seasons in hills and plateaus recorded with very low productivity. In India, plains shared about $85 \%$ crop area and rest (15\%) is contributed by hills and plateaus. Considering the country future demand of potato (125 million $\mathrm{t}$ ), the area under potato is required to increase to 3.62 million ha to meet this demand (CPRI, 2011). Exploitation of not only hills and plateau areas, but also extending areas under potato cultivation to plains during rainy seasons is indispensable. In order to analyse climatic normals of different kharif growing regions, the climatic data of Indian Meteorological Department for 15 years was collected and used. LINTUL-POTATO-DSS model was used to estimate the predicted yield of potato for kharif growing area (Haverkort et al., 2015). Hence, this review explores the prospects of kharif potatoes and future strategies for its exploitation in the low land tropics like the Indian subcontinent.

\begin{abstract}
Kharif potato scenario in India
The word Kharif denotes "Mousam" originated from Arabic; hence, it is most popular in Indian sub continent and Arabian countries. The kharif potato refers to the potato crop cultivated during rainy seasons (June to September), which is most prevealent in plateaus areas (Table 2). Although planting of potato in hills has taken place earlier than onset of rains, the crop is fully dependent on forthcoming rainy seasons for completing its life cycle. Unlike short day potato grown in plains during winter season (irrigated), kharif potato is completely grown as a rainfed crop under long day conditions, often encountering both moisture and nutritional stresses. The vigourous vegetative, late stolon formation, and stolon growth longer under long day conditions reflects the poor yield potential as compared to the short day crop (40-50 t.ha $\left.{ }^{-1}\right)$.
\end{abstract}

\section{Topographic scenario of kharif potato growing areas}

The altitude based classification of potato growing regions revealed that the crop season and crop duration of potato is location-specific (Pushkarnath, 1976). As kharif potato is grown both in hills and plateaus, the Indian hills are divided into North Indian, South Indian and North Eastern hills, which are further subdivided into Very high, High, Mid and Low hills based on the altitude (Table 3). The Northern Hills $(\mathrm{NH})$ altitude ranged between 800 and 3,000 $\mathrm{m}$ a. s. I. Due to this, the sowing time of potato ranges from early February to end of April and the harvest time lasts from early July to end of October. In Very high and high hills, the crop is completely grown under rain watering and the available crop period is longer. In Mid hills, even the kharif crop is

Contact address: Shankar Raja, ICAR-Indian Institute of Horticutural Research, Bengaluru-560089, e-mail: Raja.Shankar@icar.gov.in 
planted in February to March, there is enough soil moisture for germination and growth, but (May-June) irrigation is always essential to save the crop during dry months. Hence, the premature crop harvesting is practiced due to moisture stress which causes poor storability of tubers causing troublies with economical values. In low hills, no kharif crop is grown. The Southern hills $(\mathrm{SH})$ altitude range rises steeply even $>2,500 \mathrm{~m}$ a.s.l. at some point from the plains, they are located near $10^{\circ}$ North of equatorial line and well fixed in the tropic of cancer. Potato is grown thrice a year (Kharif or summer/ autumn/spring) at $>2,000 \mathrm{~m}$ a.s.l. elevations. As the rainy season starts during June, the crop is raised

Table 1 Top 20 Potato producing countries in the world and their seasonal trends

\begin{tabular}{|c|c|c|c|c|c|}
\hline \multirow[t]{2}{*}{ SI. No. } & \multirow[t]{2}{*}{ Countries } & \multirow{2}{*}{$\begin{array}{c}\text { Production } \\
\text { (tonnes) }\end{array}$} & \multicolumn{3}{|c|}{ Growing period } \\
\hline & & & March-September & December-May & October-April \\
\hline 1 & China & $85,920,000$ & mostly & meager & meager \\
\hline 2 & India & $45,000,000$ & meager & meager & mostly \\
\hline 3 & Russian Federation & $29,532,530$ & mostly & meager & meager \\
\hline 4 & Ukraine & $23,250,200$ & mostly & meager & meager \\
\hline 5 & USA & $19,165,865$ & mostly & meager & meager \\
\hline 6 & Germany & $10,665,600$ & mostly & meager & meager \\
\hline 7 & Poland & $9,091,900$ & mostly & meager & meager \\
\hline 8 & Bangladesh & $8,205,470$ & meager & meager & mostly \\
\hline 9 & Netherlands & $6,765,618$ & mostly & meager & meager \\
\hline 10 & France & $6,340,807$ & mostly & meager & meager \\
\hline 11 & Iran & $5,400,000$ & mostly & meager & meager \\
\hline 12 & Turkey & $4,822,000$ & mostly & meager & meager \\
\hline 13 & Canada & $4,590,296$ & mostly & meager & meager \\
\hline 14 & United Kingdom & $4,553,000$ & mostly & meager & meager \\
\hline 15 & Egypt & $4,500,000$ & meager & meager & mostly \\
\hline 16 & Peru & $4,473,503$ & meager & meager & mostly \\
\hline 17 & Algeria & $4,219,476$ & mostly & meager & meager \\
\hline 18 & Pakistan & $4,104,400$ & meager & meager & mostly \\
\hline 19 & Brazil & $3,731,798$ & meager & meager & mostly \\
\hline 20 & Malawi & $3,255,780$ & meager & meager & mostly \\
\hline
\end{tabular}

Year: 2012. Source: FAOSTAT, 2014

Table 2 Climatic characters of kharif potato compared with subtropical and temperate

\begin{tabular}{|c|c|c|c|}
\hline Parameters & Subtropics & Temperate & Kharif \\
\hline Growing season & winter & summer & rainy \\
\hline Temp. at planting & $25-30^{\circ} \mathrm{C}$ & $15-25^{\circ} \mathrm{C}$ & $25-30^{\circ} \mathrm{C}$ \\
\hline Temp. at harvesting & $10-20^{\circ} \mathrm{C}$ & $15-25^{\circ} \mathrm{C}$ & $20-25^{\circ} \mathrm{C}$ \\
\hline Crop duration (days) & $90-100$ & $150-180$ & $120-150$ \\
\hline Mid day water stress & prominent & absent & present \\
\hline Night temp. & $4-15^{\circ} \mathrm{C}$ & $15^{\circ} \mathrm{C}$ & $18-20^{\circ} \mathrm{C}$ \\
\hline Frosting & common & absent & absent \\
\hline Resulting yield & low & high & very low \\
\hline Dry matter content & less & high & high \\
\hline Growing altitude & plain & high hill & mid/high hills \\
\hline Sun shine & moderate & high & moderate \\
\hline Growing period & October-February & April-September & May-October \\
\hline
\end{tabular}


Table 3 Topographical factors of hills and plateaus regions of potato growing zones in India

\begin{tabular}{|c|c|c|c|c|c|}
\hline Hill categories & Representative location & Altitude & Latitude & Longitude & Growing season \\
\hline \multicolumn{6}{|c|}{ Northern Hills } \\
\hline Very High Hills & Kufri & - & - & - & - \\
\hline High Hills & Shimla & 2,202 & 31.06 & 77.10 & $15^{\text {th }}$ April $-30^{\text {th }}$ Oct \\
\hline Mid Hills & Almora & 1,585 & 32.08 & 76.32 & $15^{\text {th }}$ April $-15^{\text {th }}$ Oct \\
\hline Low Hills & Srinagar & 564 & 32.18 & 75.55 & $30^{\text {th }}$ June $-30^{\text {th }}$ Sep \\
\hline \multicolumn{6}{|c|}{ Southern Hills } \\
\hline Very High Hills & - & - & - & - & - \\
\hline High Hills & Ooty & 2,249 & 11.24 & 76.44 & $15^{\text {th }}$ April $-15^{\text {th }}$ Oct \\
\hline Mid Hills & Gudalore & 1,052 & 11.30 & 76.30 & $10^{\text {th }}$ April $-15^{\text {th }}$ Oct \\
\hline Low Hills & Mysore & 767 & 11.18 & 76.57 & $5^{\text {th }}$ April $-10^{\text {th }}$ Sep \\
\hline \multicolumn{6}{|c|}{ North Eastern Hills } \\
\hline Very High Hills & - & - & - & - & - \\
\hline High Hills & Shillong & 1,598 & 25.34 & 91.53 & $7^{\text {th }}$ March $-30^{\text {th }}$ July \\
\hline Mid Hills & Aijel & 1,097 & 23.44 & 92.43 & $30^{\text {th }}$ Feb $-25^{\text {th }}$ July \\
\hline Low Hills & Halflong & 682 & 25.10 & 93.12 & $10^{\text {th }}$ Feb $-10^{\text {th }}$ July \\
\hline \multicolumn{6}{|c|}{ Plateaus } \\
\hline \multirow{3}{*}{ High altitude } & Chigmangalur & 1,018 & 13.20 & 75.46 & $1^{\text {st }}$ May $-30^{\text {th }}$ Sep \\
\hline & Hassan & 967 & 12.58 & 75.59 & $30^{\text {th }}$ May $-30^{\text {th }}$ Sep \\
\hline & Dharwad & 727 & 15.27 & 75 & $10^{\text {th }}$ June $-5^{\text {th }}$ Oct \\
\hline Low altitude & Pune & 559 & 18.32 & 73.51 & $10^{\text {th }}$ June $-15^{\text {th }}$ Sep \\
\hline
\end{tabular}

during $2^{\text {nd }}$ week of April to the last week of September. However, rainfall is a basic requirement to complete the life cycle of potato in this region. The North-Eastern hills (NEH) are characterised with flat plains, undulating hillocks, hills, high plateau and mountains. In hilly areas, the potato is raised as a summer (March-July), autumn (August-December) crop where yields are generally higher in a former crop season. The high snow melts followed by rainfall take care of crop at high and very high hills. The mid and low hills completely depend on moisture through rainfall during June to September. In contrast to the very high and high hills, the growing season is warmer in mid and low hills, and therefore the crop duration is comparatively shorter.

Plateau region covers a vast area of central and peninsular India. The altitude range is from 300 to $1,200 \mathrm{~m}$ a.s.l., which are further classified into low altitude plateau (LAP) $(300$ to $600 \mathrm{~m}$ a.s.l.) and high altitude plateau (HAP) (600 to $1,200 \mathrm{~m}$ a.s.l.). In the HAP, two growing seasons (Kharif and rabi season) are feasible, while in the LAP only the winter season crop is possible. Crop season starts with the onset of pre-monsoon showers (early June) and extends up to the cessation of rains (end of September to October); hence, the growing season is fairly long. Under plateau region, the availability of potato growing days increases as the elevation increased. The low saltitude location Pune had very low days as compared to high altitude locations.

\section{Climatic and phenological siutations}

\section{Temperature}

Temperature plays a key role in determining the sowing time and consequently the duration of different phenol-phases which greatly affects the crop productivity. The climatic normals recorded for the crop season at hills and plateaus revealed that the maximum seasonal mean temperature had negative relation with altitude irrespective of hills $\left(\mathrm{NH}_{\text {, }}\right.$ $\mathrm{SH}$ and $\mathrm{NEH}$ ). The mean seasonal minimum temperature found the least at $\mathrm{NH}\left(13.04^{\circ} \mathrm{C}\right)$ as compared to $\mathrm{SH}\left(15.43^{\circ} \mathrm{C}\right)$ and $\mathrm{NEH}\left(15.51{ }^{\circ} \mathrm{C}\right)$ clearly indicated that $\mathrm{SH}, \mathrm{NEH}$ are comparatively warmer than $\mathrm{NH}$. Similarly, the seasonal mean maximum temperature was found higher at $\mathrm{NH}\left(25.95^{\circ} \mathrm{C}\right)$ as compared to $\mathrm{SH}\left(22.88^{\circ} \mathrm{C}\right)$ and $\mathrm{NEH}\left(23.84^{\circ} \mathrm{C}\right)$. In plateau regions, the mean minimum temperature observed was $19.45^{\circ} \mathrm{C}$, while the maximum mean temperature observed was $27.88{ }^{\circ} \mathrm{C}$ clearly showing a wider difference between the level of minimum and maximum temperatures between hills and plateau regions (Fig. 1).

\section{$P$ days and Growing degree days (GDD)}

Plant development requires a specific amount of heat to develop from one point in their life cycle to another (from seeding to harvesting stage). The GDD calculated for different kharif grown locations for predicting phonological events more accurately (Mc Master and Wilhelm 1997) to determine harvest dates and yield revealed that the mean $p$ days across altitudes were found lower for $\mathrm{NH}$ 
(983.2 Cd) than SH $(1,281.9 \mathrm{Cd})$ and $\mathrm{NEH}(1,281.2 \mathrm{Cd})$. Similarly, the $p$ days calculated for plateau regions across the altitude were found lower than hills (916.2 Cd), which strongly showed a negative relation of $p$ days with altitude. Growing degree (GDD) days and photo thermal units (PTU) are good estimators of growth stages. Accumulation of growing degree days and photo thermal units for each developmental stage is relatively constant and independent on the sowing date; crop variety may modify it considerably (Phadnawis and Saini 1992). The mean GDD recorded for NH was found lower $(2,069.2 \mathrm{Cd})$ as compared to $\mathrm{SH}(2,313.6$ Cd) and NEH (2,324.2 Cd). Similarly, GDD recorded for the plateau region was greater $(2,352.8 \mathrm{Cd})$ than that of $\mathrm{NEH}$ and SH (Fig. 2).

\section{Solar radiation and night temperature index}

Plants' growth rate is proportional to the amount of solar radiation received for photosynthesis, assuming that other environmental parameters are not limiting. Of the $100 \%$ total energy received by the leaf, only $5 \%$ is converted into carbohydrates for biomass production. Among the representative locations, the $\mathrm{NH}$ observed with mean solar radiation ranged from 7.23 to 12.89 with mean value of 10.18. The $\mathrm{SH}$ had ranged from 12.46 to 13.24 having mean value of 12.79 . The $\mathrm{NEH}$ recorded mean solar radiation ranging from 7.31 to 11.58 with the mean of 9.99. This data clearly indicates that $\mathrm{SH}$ received greater solar radiation as compared to the rest. Similarly in plateau region, the mean solar radiation ranged from 8.17 to 18.48 with mean value of 11.15. Similarly, the night temperature index observed ranged from 15.45 to 18.6 with mean value of 10.07 for $\mathrm{NH}$, ranging from 12.46 to 21.22 with the mean of 17.28 , and ranged from 15.87 to 19.17 with mean value of 17.56 . However, it ranged from 18.56 to 24.37 with a mean of 21.53 for pleateu regions clearly indicating that $\mathrm{SH}$, followed by plateau region, receives comparatively higher solar radiation and night temperature as compared to $\mathrm{NH}$ and $\mathrm{NEH}$. These factors strongly support the fact that the poor yield is attributed to high solar radiation as evidenced that every $1.8{ }^{\circ} \mathrm{C}$ rise in temperature could cause $3-10 \%$ yield reduction in wheat (You et al., 2009). This justifies that the enhanced radiation use efficiency for elevated temperature is imperative for plateau regions (Bradshaw, 2009).

\section{Crop growth pattern}

Varietal duration

Crop duration is determined by the heat units accumulated in the growing regions and the genotype ability to harvest

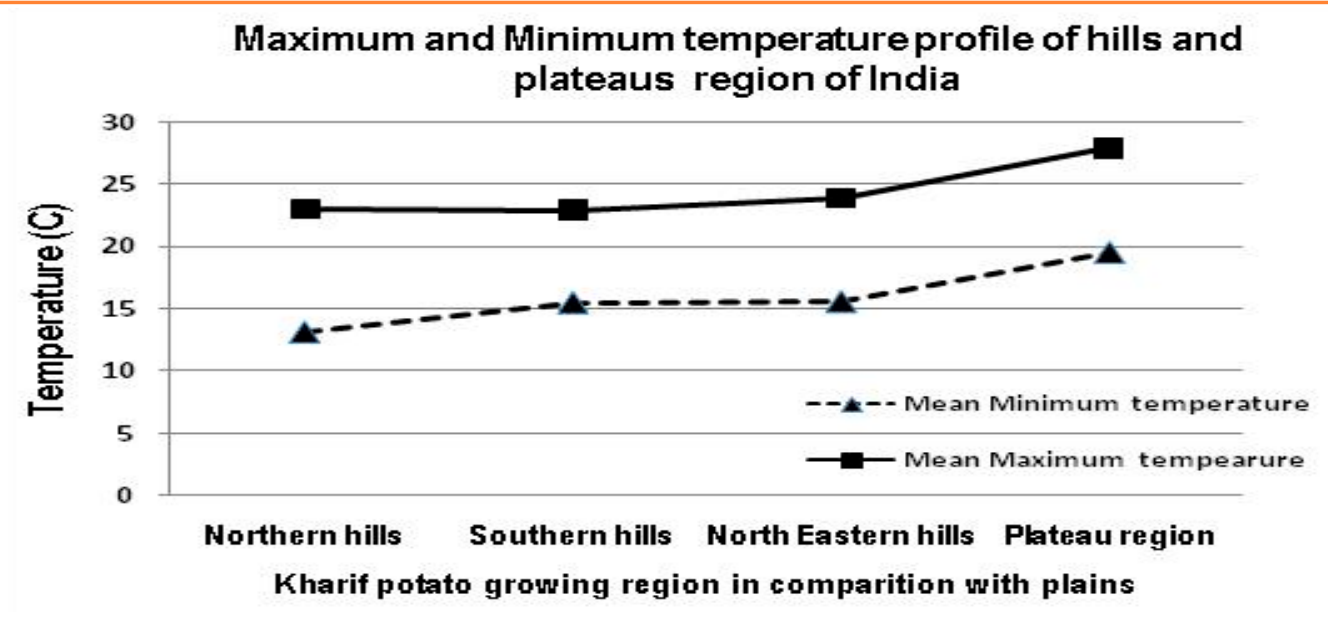

Figure 1 The mean minimum and maximum temperature profile of different kharif potato growing regions of India

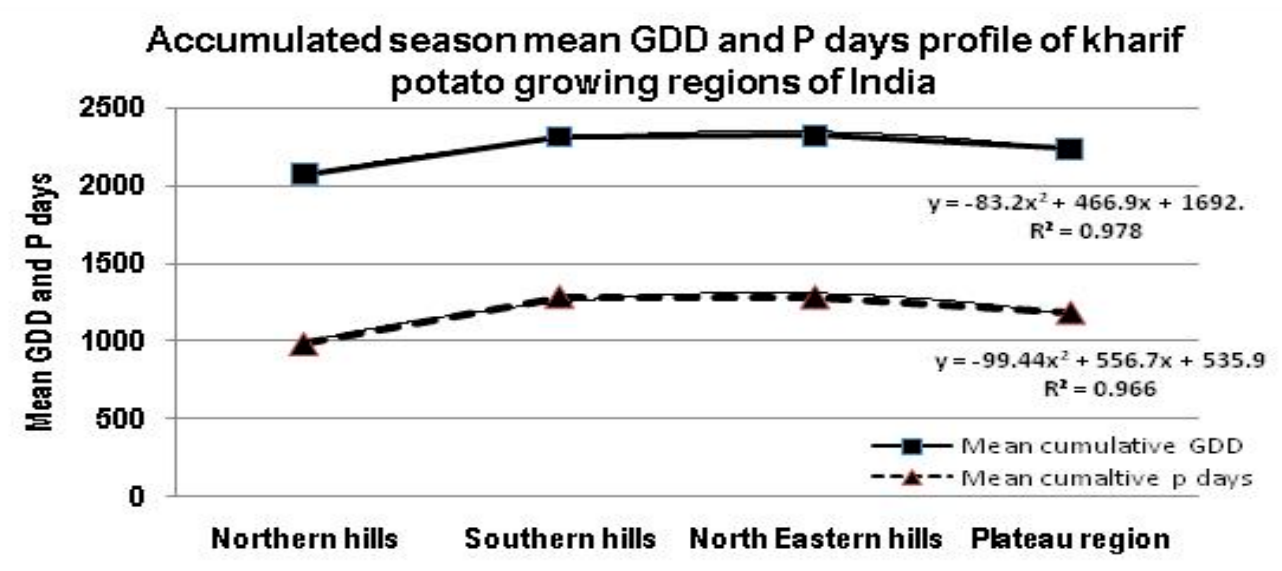

Figure 2 The growing degree days and $p$ days accumulation trend of kharif potato growing regions of India 
heat units for its growth. Although optimum temperature for potato is considered between $5{ }^{\circ} \mathrm{C}$ and $25{ }^{\circ} \mathrm{C}$, the growth period can be widened about 10-15 days on either side of the exiting window through interventions of improved varieties developed for abiotic stress factors. Considering the suitable growing temperature for tuberisation, aerial growth and development, the volume of growing degree days was calculated for kharif potato locations of hills and plateau regions. The results revealed that the $\mathrm{NH}$ had low mean GDD $(2,069.3 \mathrm{Cd})$ as compared to $\mathrm{SH}(2,313.6 \mathrm{Cd}), \mathrm{NEH}$ $(2,324.2 \mathrm{Cd})$ and plateau regions $(2,235.7 \mathrm{Cd})$, which is strongly

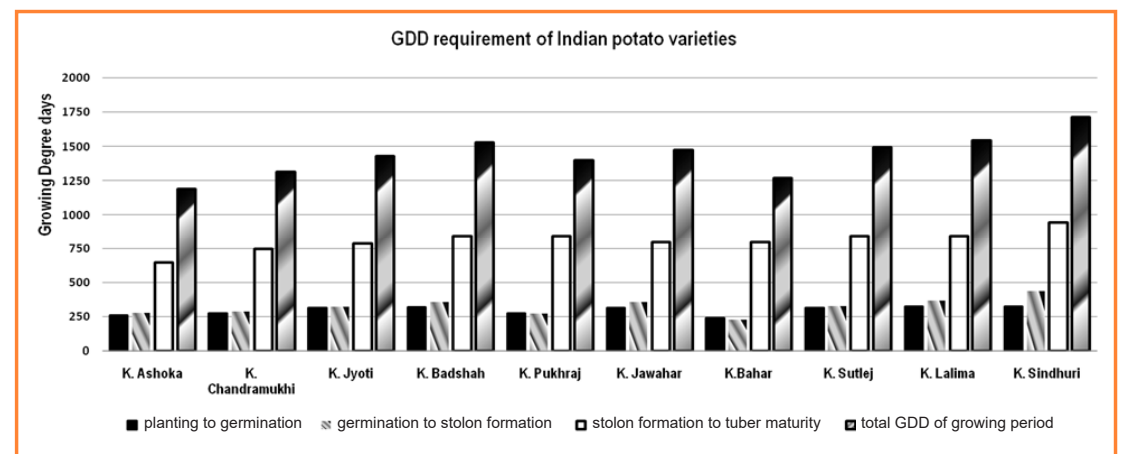

Figure 3 The growth stage wise growing degree days requirement of Indian potato varieties

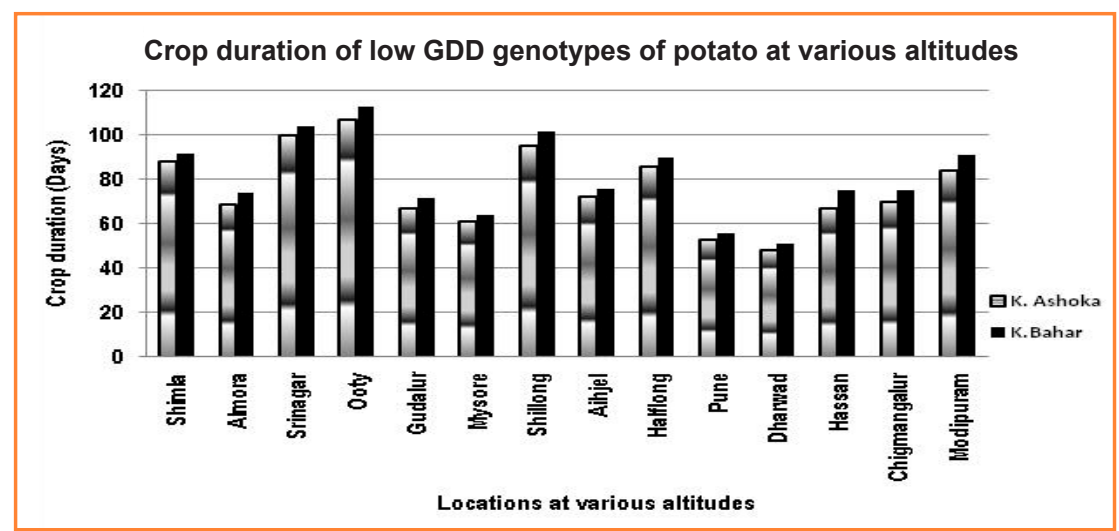

Figure 4 The location wise variation on varietal duration based on their growing degree days accumulation for low GDD potato cultivars K. Ashoka and K. Bahar supported by Hassan et al. (2007) that higher elevation areas of Canada had lower GDD at 400-800 m a.s.l. range. On the contrary, the higher GDD $(2,656.8$ Cd) recorded at plains (Modipuram) as compared to hills might be due to land use patterns of forest lands exhibiting relatively cooler GDD associated with higher evapotranspiration rates in forested areas (Hassan et al., 2007). Few exceptions showing that mid location of $\mathrm{SH}$ and $\mathrm{NEH}$ had greater GDD as compared to high hills of all the three groups can be justified by higher volume of non cloudy days (Hassan et al., 2007). Hence, the high hills required more periods to accumulate the required GDD to complete the life cycle of potato as compared to mid and low hills and plateaus. The lower hills and plateau regions had higher GDD values despite the shorter growing days due to higher maximum temperature during the crop season.

Accordingly, the varietal crop duration calculated for different altitudes based on the GDD accumulation indicated that there is a huge variation in varietal durations of the same variety at different locations. Accordingly, the stage wise GDD requirement of 10 Indian potato varieties showed varietal specificity (Singh et al., 2003). The GDD requirement from planting to germination ranged from $240 \mathrm{Cd}$ (K. Bahar) to $325 \mathrm{Cd}$ (K. Lalima and $\mathrm{K}$. Sinduri) with varieties mean value of 296.5 Cd. Similarly, the GDD required for germination to stolon formation ranged from $230 \mathrm{Cd}$ (K. Bahar) to

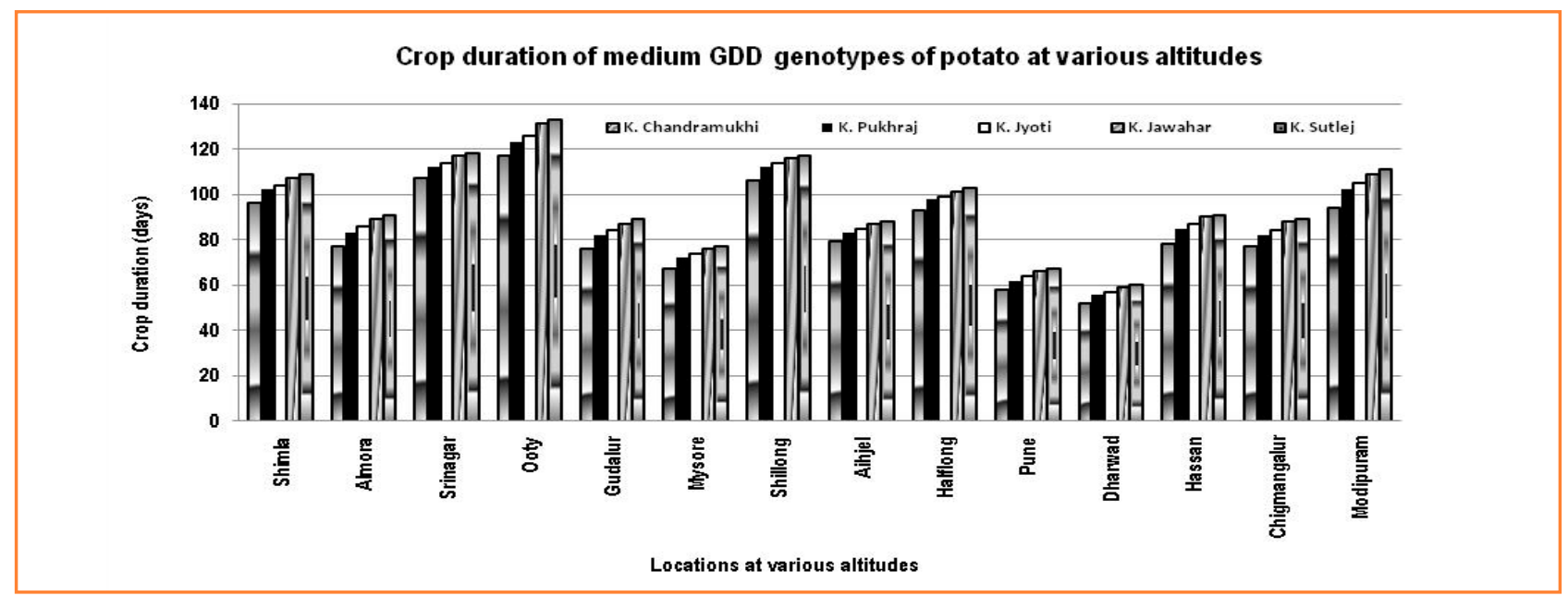

Figure 5 The location wise variation on varietal duration based on their growing degree days accumulation for medium GDD potato cultivars K. Chandramukhi, K. Pukhraj, K. Jyoti, K. Jawahar and K. Sutlej 
440 Cd (K. Sinduri) with varietal mean value of $326 \mathrm{Cd}$. For stolon formation to tuber maturity, it ranged from $650 \mathrm{Cd}$ (K. Asokha) to 950 Cd (K. Sinduri) with mean value of $814 \mathrm{Cd}$. Hence, the total GDD required for planting to tuber maturity ranged from 1,190 Cd (K. Asokha) to $1,715 \mathrm{Cd}$ (K. Sinduri) with mean value of $1,436.5 \mathrm{Cd}$ (Fig. 3 ). Based on GDD requirement, the varieties can be classified into three groups: as low, medium and long GDD varieties. The cultivar K. Ashoka and K. Bahar required comparitively lesser GDD (<1,300 Cd), K. Chandramauki, K. Pukhraj, K. Jothi, K. Jawahar, K.Badshah and K.Satluj needed moderate level (1,300-1,600 Cd) and K. Sinduri required the highest level $(>1,600 \mathrm{Cd})$. The low GDD required cultivar K. Ashoka and K. Bahar completes its life cycle at 48 \& 51days, respectively, at plateaus (Dharwad); however, they required $107 \& 113$ days, respectively, in high hills of $\mathrm{SH}$ (Ooty) due to their difference between heat unit accumulation (Fig.

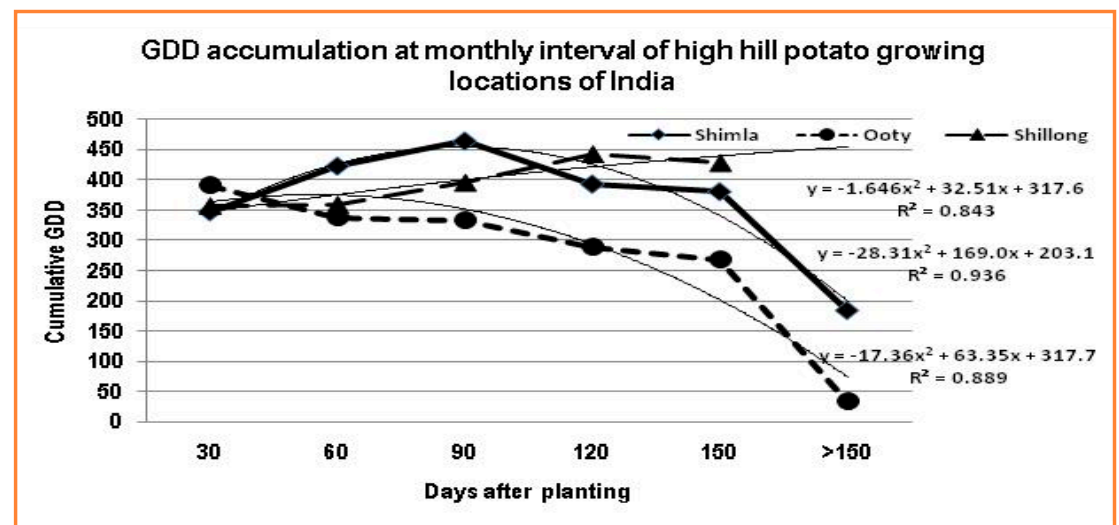

Figure 6 The mean monthly GDD accumulations and their progressive difference over high hill locations of India

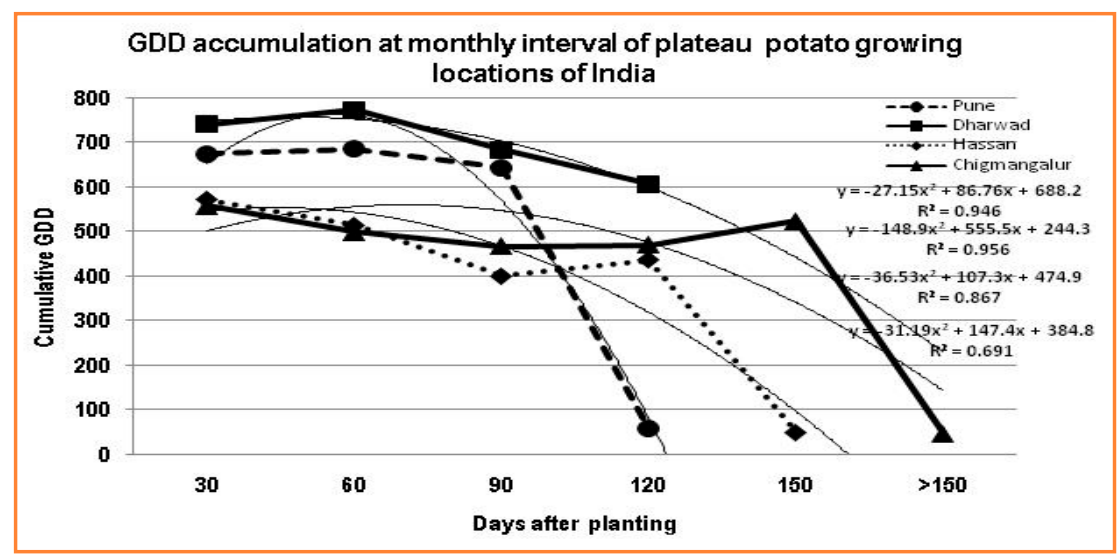

Figure 7 The mean monthly GDD accumulations and their progressive difference over plateau locations of India
4). The similar trend was observed for medium and long GDD varietes too, as K. Chandramuki (117), K. Pukhraj (123), K. Jothi (126), K. Jawahar (133) and K. Sutlej (136) required longer days at high hills of SH (Ooty) as compared to plateaus (Dharwad) $(52,56,57$, 59 and 60 days, respectively) (Fig. 5). However, these varieties needed only 94, 102, 105, 109, 111 days, respectively, at plains location (Modipuram). The long GDD required genotypes such as $\mathrm{K}$ Badshah, K. Lalima and K. Sinduri needed 60,62 and 70 days at plateaus as compared to 136 and 139 days, respectively, whereas $\mathrm{K}$ Sinduri could not recieve sufficient GDD at high hills of SH (Ooty) as the suitable growing windows were not sufficient, hence it should be harvested as premature. This finding is supported by the results of rice crop duration which was found reduced under elevated temperature $\left(>4{ }^{\circ} \mathrm{C}\right.$ of normal) to 12 days earlier (96 days), and at $>2{ }^{\circ} \mathrm{C}$ had 6 days earlier (102 days) as compared

(1) location was compared with stage wise GDD demand of the cultivars. The Indian genotypes demands GDD for germination (296.5 Cd), stolonisation (326.0 Cd) and tuber maturity stages $(814.0 \mathrm{Cd})$ revealed that the required GDD was accumulated at 30 DAP for germination and 60 DAP for stolonisation, irrespective of hills. However, from stolonisation to tuber maturity it demanded higher GDD, which is fulfilled only at NEH and $\mathrm{NH}$ (>350 Cd). On the other hand, in $\mathrm{SH}$ the GDD was descending $<350 \mathrm{Cd}$ (Fig. 6), which necessitates greater radiation use efficient cultivars for $\mathrm{SH}$ for achieving higher yield. On the contrary, the growth stage wise GDD accumulated in plateaus were exorbitantly higher than the GDD required for Indian genotypes (Fig. 7); hence the selection or developing new early matuting cultivars with greater radiation use efficiency is further enhancing the yield.

\section{Environment exploitation for higher tuber yield}

A little yield progress has been achieved in mid-early and late potato cultivars (Schuster, 1997) of German federal 
varieties (Douches et al., 1996) and U.S. potato cultivars for a period of three decades which strongly explained the lack of yield improvement in early maturity genotypes of the most modern cultivars. In India, too, the coefficient of variation on area and production variability analysed for decade period revealed greater yield variability from high yield to high variability and low yield to low variability among potato growing states (Saxena and Mathur, 2013). The lower yield coupling with low/high yield variability states are the areas where unfavourable weather prevails with biotic and abiotic stress pressure and lack of ideal varieties resulting in their low yields (Sananse, Borude and Patil, 1990). Hence, modifying phonological patterns of crop is a prime requisite to avoid or minimize stress (Lopes and Reynolds, 2010) as efficient management on phonological basis is determined by Incident solar radiation (Monteith and Unsworth, 1990), radiation use efficiency (Mitchell, Sheehy and Woodward, 1998; Sinclair and Muchow, 1999) and harvest index (Belanger et al., 2001).

Long back, Donald (1968) designed a plant ideotype for small grain cereal having a short stem, a few erect leaves, a high harvest index and erect an ear and a single culm. The two hundred years of modern breeding of potato has resulted in a great diversity of modern lines; however, genotypic variation for photosynthetic traits is still lacking (Street et al., 2009) and reflects the necessity of ideotype breeding. The modern potatoes have a high harvest index of around 0.80 and potential yields of 140 t.ha $^{-1}$ (Mackay, 1996: Beukema and van der Waag, 1990) depending upon the length of growing season and temperatures. In tropics and sub-tropics, the possibility to reach the level of yields obtained in temperate zone is remote due to its shorter growing season and a lower efficiency per unit of intercepted radiation. However, kharif potato has a greater scope for yield exploitation through enhancing radiation use efficiency and light interception characteristics as it is grown under long day conditions with long growing period. Hence, the transition from qualitative to quantitative and from morphological to phonological traits in designing crop ideotype is essential to nullify the environment effect (Hunt, 1993) through species selection to plant architecture modification.

\section{Species selection}

Prioritising the plains, the Indian potato breeding program is focused mainly on Species Solanum andigena due to its ability to tuberisation under short day conditions as against S. tuberosum (long day conditions). Hence, Tuberosum (female) $\times$ short-day Andigena hybrids were used for the sub-tropic plains of India, these hybrids showed a yield advantage of $19 \%$ over Tuberosum $\times$ Tuberosum hybrids in the second clonal generation at harvest 120 days after planting (Gopal, Chahal and Minocha, 2000) although Andigena parents were lower yielding as compared to Tuberosum (6.02 versus $10.78 \mathrm{~kg} \mathrm{plot}^{-1}$ ). As a result, a number of Indian potato cultivars have been developed from Tuberosum $\times$ Andigena crosses, including K. Pukhraj, K. Giriraj, K. Chipsona-2 and K. Shailja (Kumar et al., 2008). However during the same period in sixties, the long-day adapted Andigena (Neotuberosum) potatoes parents were used in European and North American breeding programmes (Glendinning, 1975) for long day conditions. The Tuberosum $\times$ long-day Andigena hybrids have shown yield advantages of 7 to $21 \%$ over Tuberosum $\times$ Tuberosum hybrids. Mass selection method adopted to produce a population of S. phureja/S. stenotomum for long-day North European conditions (Carroll, 1982), and achieved average 26\% higher yielding hybrids than five Tuberosum cultivars (Pentland Crown, Desiree, Maris Piper, Pentland Dell and Record) (Carroll and De Maine, 1989). Cubillos and Plastid (1976) found that under short days in Mexico, Colombia and Peru, long-day-adapted (Andigena $\times$ Andigena) hybrids outyielded Tuberosum $\times$ Tuberosum hybrids and in Colombia they also outyielded their Tuberosum $\times$ longday Andigena hybrids. Hence, breeding for kharif potato needed Neotuberosum, S. phureja/S. stenotomum parents based offspring to attain yield rather than S. tuberosum $\times$ S. andigena (short day adapted) based offsprings.

\section{Plant architecture}

Plant architecture is a three-dimensional organization of a part of a plant, encompassing branching pattern, plant height, leaves arrangement and the structure of reproductive organs which determines its adaptability to cultivation, harvest index and potential yield (Reinhardt and Kuhlemeier, 2002). Under kharif season, plant height had significantly positive correlation with number of leaves per plant, and in turn, the number of leaves had positive and significant correlation with days to tuber initiation, days to tuber maturity and tuber weight (Amadi, Ene-Obong and Okoc, 2008) justifies the delay in tuber initiation perhaps allowing for optimal foliage development before tuber initiation phase, and consequently delay in maturity allows for a longer period for the storage of assimilates, implying the taller plant with late maturity group suits for higher hill regions. A significantly negative correlation between tuber yield and days to tuber initiation; and days to maturity suggested that an early bulking coupled with a sustained partitioning of assimilates to tubers invariably lead to higher yield (Amadi and Ene-Obong, 2007) indicating early bulking genotypes suits invariably for mid and low hill regions. Fekadu, Petros and Zelleke (2013) found that tuber yield had positive correlation with plant height, biological yield, harvest index and big tuber percentage, while and negatively correlating with small and medium tuber percentage at both the phenotypic and genotypic levels. The greater genetic variability in potato for plant height (189 to $728 \mathrm{~mm}$ ), plant spread (146 to $542 \mathrm{~mm}$ ) and leaf area ( 88.6 to $217.5 \mathrm{~cm}^{2}$ ) have higher phenotypic coefficient value than the genotypic value (Regassa and Basavaraj, 2005) and these traits had moderate heritability coupled with low genetic advance indicating that these traits can be improved by the hybridization method.

Fine-tuning the vegetative-to-reproductive growth balance is a way to manipulate varieties showing different growth habits (Spielmeyer, Ellis and Chandler, 2002). In potato, the vegetative peak reaches at about 60 days of planting (source) supplies sink to the tuber which start initiating at 35 days of growth. Tuber initiation involves a shift from stolon elongation to radial swelling of the subapical region, accompanied by a decline of alkaline and 
acidic invertase, and an increase of sucrose synthase and fructokinase activity (Ross et al., 1994). The rise in sucrose synthase and fructokinase activities is positively correlated with the onset of starch and storage protein biosynthesis (Ross et al., 1994). Hence, the first formed tubers are larger in size due to dominance sink causing poorly developed tuber in latter forming stolon due to sink strength in tubers. In order to prolong and uniform tuber size, the ensured and balanced source and sink relation is maintained in semi-determinate growth genotypes. In similar line, stem characters and stem diameter exhibiting poly genes with additive genetic effect had highly positive correlation with $1,000-K W$ (kernal weight) and GYPS (grain yield per stem) in wheat genotypes. Hence, semi-determinate with erect stem genotype would yield better by manipulation in sink and source relation in potato for kharif environments.

\section{Leaf morphology and its orientation}

Dickinson, Parker and Strauss (1987) reported that differences in leaf shape are often more inheritable and independent on the environment. The genetic variability for leaf morphology (Hue, Chandran and Boyce, 2010), and the larger leaf surface area is associated with increasing light absorption. Genetic variation reported for leaf number per plant ranged from 30.3 (Granola) to 93.3 (Agria) and it is genotype-specific (Ozturk and Yildrim, 2014). The presence of complex edges and lobes in larger leaves enables to disperse the absorbed heat very rapidly, and waxy surface in younger leaves prevents or minimise the transpiration rate as they locate at the top of the plant (C.I.P., 2008). In many species, vein density has been correlated with hydraulic conductivity of water and maximum photosynthetic rate in leaves (Brodribb, Field and Jordan, 2007) and the smaller leaf area has been associated with greater vein density that may contribute to increased abiotic stress tolerance (Scoffoni et al., 2011). Irrespective of shape and size of leaf, Leaf Area index (LAI) has been defined as the area of green leaves per unit area of the ground (Jonckeere, 2004), a higher and lower value of LAI indicating a denser and sparse crop canopy, respectively (Boken and Chandra, 2012). LAI is a stage of genotype and its growing condition specific (Lopes et al., 2013). In potato, LAl ranged from 1.40 (Dakchip) to 6.60 (Pungo), where the maximum LAl recorded at 61 DAP (Monalisa) (Nunes et al., 2006). However, the cv. Atlantic, Chipbelle and DTO-33 showed no decline in their LAI up to 73 days of planting (DAP) indicating a better abiotic stress tolerance response. Leaf area expansion is a determinant of crop growth rate (Goudriaan and van Laar, 1994); it increases with LAI particularly at early growth stages, because the relative increases in the interception of photosynthetically active radiation (IPAR) are largest when leaf is small (Jamieson et al., 1998). Potato genotypes with warmer crop canopies under irrigated conditions are less susceptible to drought than genotypes with cooler canopies (Stark, Pavek and McCann, 1991) due to the rate of transpiration driven cooling of the leaves. Genetic manipulation of leaf angle is not complex, and is thought to be controlled by only two to three genes. In Dasiree, the dry matter distribution pattern that diverted substantially and tuber filling started earlier than the cultivars of same maturity group, but during tuber filling a greater proportion of the assimilate diverted in the leaf growth (Spitter and Schapendock, 1990) indicates the suitability of erectophile leaf with medium to late bulking genotypes for kharif season where later growth stage seldom faces moisture stress in the soil due to adequate rainfall.

Leaf morphology determines leaf photosynthetic rate which can be improved by breeding (Crosbie, Pearce and Mock, 1981) and progress could be achieved for high photosynthetic $\mathrm{CO}_{2}$ exchange rate (Mahon and Hobbs, 1981). The canopy photosynthesis on ground cover basis was ranged from 1.72 to $4.34 \mathrm{~g} \mathrm{CO}_{2} \cdot \mathrm{m}^{-2} \cdot \mathrm{hr}^{-1}$ (Bhagsari, 1988), cv. Pungo had higher values than other genotypes. The mean adaxial and abaxial stomatal conductance was 0.86 and $1.46 \mathrm{~cm} \cdot \mathrm{sec}^{-1}$, respecively. Dry matter partitioning to tubers ranged from $8.9 \%$ (Pungo) to $55.5 \%$ (Atlantic) $67 \mathrm{DAP}$ and the tuber yield ranged from 9.6 to $27.8 \mathrm{MT}^{\mathrm{h}} \mathrm{ha}^{-1}$, indicating the suitability of cultivar Atlantic for growing in a warm climate. Cieply (1976) concluded that assimilation rates can be used as a physiological criterion for rapid selection in potato breeding. Measured rates of $\mathrm{CO}_{2}$ uptake by 18 clones of potato under standard conditions (Mol and Henniger, 1978) and the stomatal number per leaf at upper surface ranged from 4 (A6948) to 50 (A66107-51). The area of stomatal apparatus was also found to range from 0.1 to 2.2 at upper surface and 6.8 and 9.6 at lower surface of respective potato clones. However, the $\mathrm{CO}_{2}$ uptake was found higher in clone A-6948 (9.2) as compared to A-66107-51(7.6 mg CO $\mathrm{mg}^{-1}$.chl.h ${ }^{-1}$ ), giving a surprising contribution to total carbon assimilation that Lemhi has an unusually high rate of $\mathrm{CO}_{2}$ assimilation through the upper leaf surface, and A6948-4 an unusually high rate through the lower leaf surface; through breeding, these two characters can be combined for the high carbon assimilation rates of Lemhi's upper leaf surface and A69484's lower leaf surface. The greater leaf carbon exchange rate of Dara-5 transgenic plants did not result in increased yields which is explained by poor C-use efficiency, low sink strength of the tubers, or both (Schittenhelm, Sourell and Löpmeier, 2006). The transgenic plants exhibited relatively higher investment of biomass into photosynthetic leaf area, stems, and roots and less to tubers than the nontransgenic plants due to the differing rate of dark respiration among the parts (Vose and Ryan, 2002) because tubers have lower respiration rates than other potato plant parts, especially leaves (Winkler, 1971).

\section{Root architecture and drought tolerance}

Manpulation of root architecture is imperative for kharif potato as it frequently encounters nutritional deficiency and drought stress. In general, potato cultivars are shallow rooted and often produce most of their roots in the plough layer (Iwama, 2008; Iwama and Yamaguchi, 2006). However, an inhibition of root growth by high soil strength greater than $1 \mathrm{MPa}$ under rainfed situation (Miller and Martin, 1987) results in low harvest index as against an irrigated crop with high harvest index (Vos and Haverkort, 2007). A wider variation for root traits in European tetraploid potato (S. tuberosum Group Tuberosum), diploid Phureja potatoes (S. tuberosum Group Phureja) and Neotuberosum lines (selected from S. tuberosum Group Andigena) has been observed (Wishart et al., 2009). The total root 
length per plant varied from $0.38 \mathrm{~m}$ (Tuberosum variety Pentland Dell) to $>100 \mathrm{~m}$ (Phureja variety Mayan Twilight). Phureja line (Mayan Gold) had the longest and thinnest roots. The number of stolon roots and basal roots amongst the cultivars varied, the Phureja line, Mayan Gold, had significantly more of both root classes, their relative proportions too, suggesting potential genetic difference in resource partitioning. A positive correlation between root pulling resistance and tuber yield (Wall et al., 2006) and root mass correlates well with leaf mass, and tuber yield (Deguchi et al., 2010) observed earlier simplifies overcoming difficulty in root studies in potato. Most $\mathrm{N}$ efficient hybrid JX-576 had significantly higher mean root length, root surface area, and root volume than least $\mathrm{N}$ efficient cultivar Kufri Jyothi (Trehan and Singh, 2013). Average tuber yield reduction per $\mathrm{mm}$ water deficit has been estimated at $117 \mathrm{~kg} \mathrm{ha}^{-1}$ (Vos and Groenwold, 1988) and a decrease of leaf water potential from -0.5 to $-0.9 \mathrm{MPa}$ reduced photosynthesis by $58 \%$ and it decreased the internal $\mathrm{CO}_{2}$ concentration by $29 \%$ (Vos and Oyarzun, 1987). The $\mathrm{CO}_{2}$ concentration and assimilation are positively correlated and a $10 \%$ increase in tuber yield is estimated for every $100 \mathrm{ppm}$ increase in $\mathrm{CO}_{2}$ concentration (Miglietta et al., 1998). The simulation study of 16 potato growing locations also indicated that locations viz., Chitoor and Kolar appear to be ideal for screening studies as the night temperature at these locations is between 20 and $22{ }^{\circ} \mathrm{C}$ for most of the crop season and varieties with heat tolerance greater than K. Surya can be selected at these locations (Minhas et al., 2011). K. Surya has been identified for successful growing of potato for these areas where at least 70 days are available with night temperatures ranging from 18 to $22^{\circ} \mathrm{C}$. Thus, it is suitable for most parts of peninsular and coastal India e.g., in the Andaman and Nicobar islands the variety gave a yield of 14 t.ha' (Minhas et al., 2011).

Hypothetical attainable yield estimation through ideotype breeding approach for kharif areas.

In addition to the yield determinant traits, the available length of the growing season also determines the yield (Haverkort, 1990). The high hills had suitable temperatures for longer duration and longer rainfall season necessitates the demands for late variety which should utilise the long growing season for better yields as compared to early varieties. The low GDD varieties (K. Ashoka and K. Bahar) comes to harvest very early at high hills (86-113 days), plateaus (48-75 days) and plains (84-91 days), revealing the more unutilised suitable growing period due to senescence of present day varieites. The medium GDD varieties such as $\mathrm{K}$ Chandramuki, K. Pukhraj, K. Jothi, K Jawahar and K. Sutlej also complete growth cycle within $96-133$ at high hills, $76-88$ at mid hills, 67-118 days at low hills, 52-91 days at plateaus and 94-111 days in the plains reflecting more unutilised suitable growing period. Similar trend has been observed for high GDD varieties such as K Badshah, K. Lalima and K. Sinduri across growing locations.

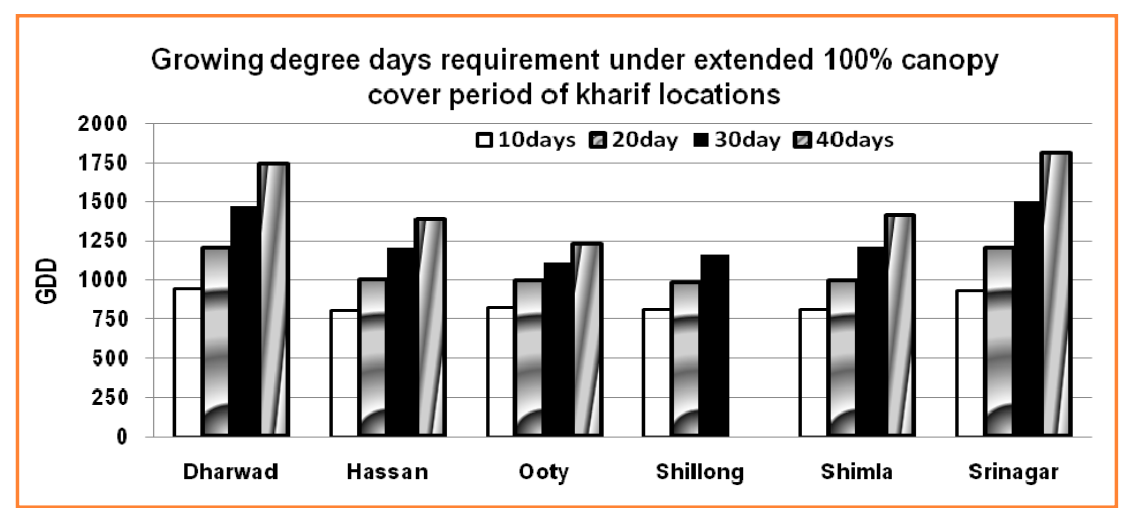

Figure 8 Growing degree days accumulation at extended 100\% canopy cover for 40 days at various kharif potato growing locations

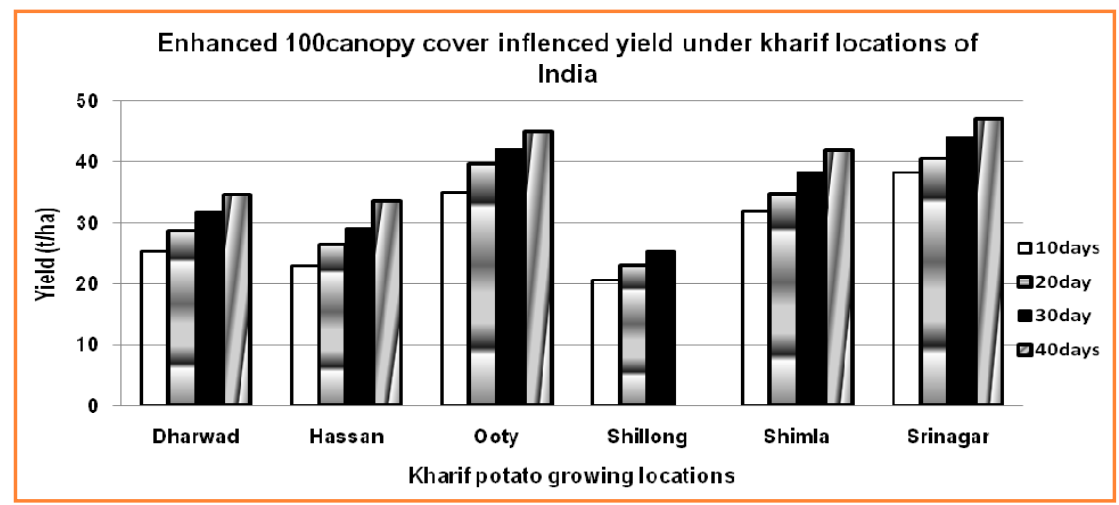

Figure 9 The predicted yield variation for extended 100\% canopy cover for 40days at various kharif potato growing regions 
canopy cover (100\%) duration extended by 10, 20, 30 and 40 days. By increasing canopy cover (100\%) to 40 days, the GDD accumulation during the growing season could be enhanced upto $800 \mathrm{Cd}$ (Dharwad), $585 \mathrm{Cd}$ (Hassan et al., 2007), 406 Cd (Ooty), 602 Cd (Shimla) and 886 Cd (Srinagar) additionally in different kharif areas. Under the condition of harvesting of the additional heat units and converting in terms of drymatter, the attainable yield of 25.4, 28.7, 31.7 and 34.7 t.ha $^{-1}$, respectively, could be obtained at Dharwad. Similarly, the values of $31.9,34.9,38.3$ and 42.0 t.ha $^{-1}$ were indicated for Shimla (Fig. 8).

It has also resulted from the fact that despite higher heat unit accumulation in Dharwad and Srinagar, the attainable yield could reach up to 34.7 and 47.1 t.ha $^{-1}$, respectively (up to 30 days only). However, the locations Ooty and Shimla register higher values for attainable yield (45.1 and 42.0 t.ha $^{-1}$, respectively) despite the low level of heat accumulation $\left(<1,500^{\circ} \mathrm{Cd}\right)$. In Shillong, the $100 \%$ canopy cover cannot be expanded for 40 days of its attainment due to the lack of suitable growing period for potato $\left(<1,250^{\circ} \mathrm{Cd}\right)$ (Fig. 9).

\section{Way Forward}

Presently, kharif potato is complexly a long day crop grown mainly rainfed in hills and plateaus, and affected by high temperature during rainy season in plains; the area under kharif potatoes has not extended to plains. Developing an ideal phenotype having traits introgressed using physiological breeding approach for enhanced radiation and light use efficiency under longday/day neutral background is imperative. The yield in potato under stress free conditions is determined by the canopy cover, radiation use efficiency and partitioning ratio of genotypes. The amount of total radiation intercepted by green active foliage depends on the amount of solar radiation and on the proportion that intercepted (based on the Leaf area index, leaf angle and scattering nature of leaf). The size and shape of the leaves with complex edges are associated with stress tolerance and dispersion of absorbed heat is a very desirable trait in heat stressed environments. The vein density has been correlated with hydraulic conductivity of water and maximum photosynthetic rate in leaves (Brodribb, Field and Jordan, 2007) and enhanced water use efficiency.

Improvement in root traits like root depth and root length density is important for developing cultivars for rainfed condition. Wider variation in rooting traits of a range of potato genotypes including the European tetraploid potato, diploid and Neotuberosum lines showed the total root length per plant varied from $38 \mathrm{~m}$ (Tuberosum variety Pentland Dell) to $>100 \mathrm{~m}$ (Phureja variety Mayan Twilight) (Wishart et al., 2009). A positive correlation found between root pulling resistance and tuber yield, root mass correlates well with leaf mass and tuber yield (Deguchi et al., 2010) could be used as an indices for selecting ideal parental line for kharif potato breeding program. Hence, a phenotype having semi determinate growth type with erectophile lobed leaf margins of waxy surface having dense venation at arial and higher root diameter with higher tuber surface roots at underground coupling of higher radiation and light use efficiency is ideal for kharif potatoes.

\section{References}

AMADI, C.O. - ENE-OBONG, E.E. 2007. Genetic variability and interrelationships of some potato attributes in Jos Plateau, Nigeria. In Nigerian Journal of Botany, vol. 20, 2007, no. 1, pp. 233-245.

AMADI, C.O. - ENE-OBONG, E. E. - OKOC, B. E. 2008. Path analysis of yield of some potato hybrids and their progenitors in Northern Guinea Savanna of Nigeria. In PAT, vol. 4, 2008, no. 2, pp. 28-37.

ARTHI RANI, B. - MARAGATHAM, N. 2013. Effect of elevated temperature on rice phenology and yield. In Indian Journal of Science and Technology, vol. 6, 2013, no. 8, pp. 5096-5098.

BELANGER, G. - WALSH, J.R. - RICHARDS, J.E. - MILBURN, P.H. ZIADI, N. 2001. Tuber growth and biomass partitioning of two potato cultivars grown under different $\mathrm{N}$ fertilization rates with and without irrigation. In American Journal of Potato Research, vol. 78, 2001, pp. 109-117.

BEUKEMA, H.P. - VAN DER WAAG, D.E. 1990. Introduction to potato production. Wageningen : Pudoc, 1990, pp. 23-24.

BHAGSARI, A.S. 1988. Photosynthesis and stomatal conductance of selected root crops as related to leaf age. In Crop Science, vol. 28, 1988, pp. 902-906.

BOKEN, V.K. - CHANDRA, S. 2012. Estimating leaf area index for an arid region using spectral data. In African Crop Science Journal, vol. 20, 2012, no. 4, pp. 215-223.

BRADSHAW, J.E. 2009. A Genetic perspective on yield plateau in potato. In Potato J., vol. 36, 2009, no. 3-4, pp. 79-94.

BRODRIBB, T.J. - FIELD, T.S. - JORDAN, G.J. 2007. Leaf maximum photosynthetic rate and venation are linked by hydraulics. In Plant Physiology, vol. 144, 2007, pp. 1890-1898.

CIEPLY, J. 1976. The productivity of photosynthesis of several varieties of spring barley and potatoes as an index of their fertility (Abstr.). Krakow : RepAcadAgric, 1976.

C.I.P. 2008. Inte rnational Potato Center (ICP). 2008. www.cipotato. org/sweetpotato/

CARROLL, C.P. 1982. A mass-selection method for the acclimatization and improvement of edible diploid potatoes in the United Kingdom. In Journal of Agricultural Science Cambridge, vol. 99, 1982, pp. 631-640.

CARROLL, C.P. - DE MAINE, M.J. 1989. The agronomic value of tetraploid $F_{1}$ hybrids between potatoes of group Tuberosum and group Phureja/Stenotomum. In Potato Research, vol. 32, 1989, pp. 447-56.

CPRI. 2011. Vision 2030. Central Potato Research Institute, Shimla, India, 2011, $40 \mathrm{p}$.

CROSBIE, T.M. - PEARCE, R.B. - MOCK, J.J. 1981. Recurrent phenotypic selection for high and low photosynthesis in two maize populations. In Crop Science, vol. 21, 1981, pp. 736-740.

CUBILLOS, A.G. - PLAISTED, R.L. 1976. Heterosis for yield in hybrids between S. tuberosum ssp. Tuberosum and tuberosum ssp. andigena. In American Potato Journal, vol. 53, 1976, pp. 143-150.

DEGUCHI, T. - NAYA, T. - WANGCHUK, P. - ITOH, E. - MASSUMOTO, M. - ZHENG, X. - GOPAL, J. - IWAMA, K. 2010. Aboveground characteristics, yield potential and drought tolerance in "Konyu" potato cultivars with large root mass. In Potato Research, vol. 53, 2010, pp. 331-340.

DICKINSON, T.A. - PARKER, W.H. - STRAUSS, R.E. 1987. Another approach to Leaf Shape Comparisons. In Taxonomy, vol. 36, 1987, no. 1, pp. 1-20.

DONALD, C.M. 1968. The breeding of crop ideotype. In Euphytica, vol. 17, 1968, pp. 385-403.

DOUCHES, D.S. - MAAS, D. - JASTRZEBSKI, K. - CHASE, R.W. 1996. Assessment of potato breeding progress in the USA over the last century. In Crop Science, vol. 36, 1996, pp. 1544-1552. 
FAO. 2014. Statistical databases FAOSTAT. http://faostat.fao.org/ site/567/default. aspx\#ancor, 2014.

FEKADU, A. - PETROS, Y. - ZELLEKE, H. 2013. Genetic variability and association between agronomic characters in some potato (Solanum tuberosum L.) genotypes in SNNPRS, Ethiopia. In International Journal of Biodiversity and Conservation, vol. 5, 2013, no. 8, pp. 523-528.

GLENDINNING, D.R. 1975. Neo-Tuberosum: New potato breeding material. 2. A comparison of Neo-Tuberosum with unselected Andigena and with Tuberosum. In Potato Research,vol. 18, 1975, pp. 343-350.

GOPAL, J. - CHAHAL, G.S. - MINOCHA, J.L. 2000. Progeny mean heterosis and heterobeltiosis in Solanum tuberosum $\times$ tuberosum and $S$. tuberosum $\times$ andigena families under a short day sub-tropic environment. In Potato Research, vol. 43, 2000, pp. 61-70.

GOUDRIAAN, J. - VAN LAAR, H.H. 1994. Modelling potential crop growth processes. Dordrecht : Kluwer Academic Publishers, 1994.

HASSAN, Q.K. - CHARLES, P. - BOURQUE, A. - MENG, F.R. - RICHARDS, W. 2007. Spatial mapping of growing degree days: an application of MODIS-based surface temperatures and enhanced vegetation index. In Journal of Applied Remote Sensing, vol. 1, 2007, pp. 1-12. HAVERKORT, A. J. 1990. Ecology of potato cropping systems in relation to latitude and altitude. In Agricultural Systems, vol. 32, 1990, no. 3, pp. 251-272.

HAVERKORT, A.J. - FRANKE, A. C. - STEYN, J. M. - PRONK, A. A. CALDIZ, D. O. - KOOMAN, P. L. 2015. A Robust Potato Model: LINTULPOTATO-DSS A. In J. Potato Research, 2015, no. 58, pp. 313-327.

HUE, S.M. - CHANDRAN, S. - BOYCE, A.N. 2010. ISHS Acta Horticulturae 943: Asia Pacific Symposium on Postharvest Research, Education and Extension 1 Variationsof Leaf and Storage Roots Morphology in Ipomoea batatas L. (Sweet potato) Cultivars. ISHS Acta Horticulturae. 2010, 943: Asia Pacific Symposium on Postharvest Research, Education and Extension.

HUNT, S. C. - HASSTEDT, S. J. - WU, L. L. - WILLIAMS, R. R. 1993. A gene-environment interaction between inferred kallikrein genotype and potassium. In Hypertension, vol. 22, 1993, no. 2, pp. 161-168.

IWAMA, K. 2008. Physiology of the potato: New insights into root system and repercussions for crop management. In PotatoResearch, vol. 51, 2008, pp. 333-353.

IWAMA, K. - YAMAGUCHI, J. 2006. Chapter 7. Abiotic Stresses. In Handbook of potato production, improvement, and postharvest management, ed. Gopal, J. - Khurana, S.M.P., New York : The Haworth Press, 2006, pp. 231-278.

JAMIESON, P.D. - SEMENOV, M.A. - BROOKING, I.R. - FRANCIS, G.S. 1998. Sirius: a mechanistic model of wheat response to environmental variation. In European Journal of Agronomy, vol. 8, 1998, pp. 161-179.

JONCKHEERE, I. - FLECK, S. - NACKERTS, K. - MUYS, B. - COPPIN P. - BAREF, M. 2004. Review of methods for in situ leaf area index determination: theories, sensors and hemispheral photography. In Agricultural and Forest Meteorology, vol. 121, 2004, no. 1-2, pp. 19-35.

KUMAR, R. - KUMAR, V. - GOPAL, J. - LUTHRA, S.K. - PANDEY, S.K. 2008. Inventory of Potato Germplasm (Group Andigena) Collection. In Technical Bulletin, CPRI, Shimla, India, 2008, no. 86.

LOPES, M.S. - REYNOLDS, M.P. 2010. Partitioning of assimilates to deeper roots is associated with cooler canopies and increased yield under drought in wheat. In Functional Plant Biology, vol. 37, 2010, pp. 147-156.

LOPES, E.C. - JADOSKI, S.O. - SAITO, L.R. - SCHEIFITER DE RAMOS, M. 2013. Plant morphological characteristics and yield of Potato cV. Agata in function to fungicides application. In Brazilian Journal of Applied Technology for Agricultural Science, Guarapuava-PR, vol. 6, 2013, no. 1, pp. 37-46.
MACKAY, G.R. 1996. An Agenda for future potato research. In Potato Res, vol. 39, 1996, pp. 387-394.

MAHON, J.D. - HOBBS, S.L. 1981. Selection of peas for photosynthetic $\mathrm{CO}_{2}$ exchange rate under field conditions. In Crop Science, vol. 21, 1981, pp. 616-621.

MC MASTER, G.S. - WILHELM, W.W. 1997. Growing degree-days: one equation, two interpretations. In Agricultural and Forest Meteorology, vol. 87, 1997, no. 4, pp. 291-300.

MILLER, D.E. - MARTIN, M.W. 1987. The effect of irrigation regime and subsoiling on yield and quality of three potato cultivars. In American Potato Journal, vol. 64, 1987, pp. 17-25.

MIGLIETTA, F. - MAGLIULO, V. - BINDI, M. - CERIO, L. - VACCARI, F.P. - LODUCA, V. - PERESSOTTI, A. 1998. Free air $\mathrm{CO}_{2}$ enrichment of potato (Solanum tuberosum L.): development, growth and yield. In Global Change Biology, vol. 4, 1998, pp. 163-172.

MINHAS, J.S. - RAWAT, S. - GOVINDAKRISHNAN, P.M. - KUMAR, D. 2011. Possibilities of enhancing potato production in nontraditional areas. In Potato Journal, vol. 38, 2011, no. 1, pp. 14-27.

MITCHELL, P.L. - SHEEHY, J.E. - WOODWARD, F.I. 1998. Potential yields and the efficiency of radiation use in rice. IRRI Discussion Paper Ser. 32. Manila : IRRI, 1998.

MOL, L. - HENNIGER, A.W. 1978. Genotypische Photosynthescratevon Kartoffeln und ihre Mogliche RoUe fur die Ertagsbildung. In Photosynthetica, vol. 12, 1978, pp. 51-61.

MONTEITH, J.L. - UNSWORTH, M.H. 1990. Principles of environmental physics, $2^{\text {nd }}$ ed., Oxford : Butterworth, 1990.

NUNES, J.C.S. - FONTES, P.C.R. - ARAUJO, E.F. - SEDIYAMA, C. 2006. Crescimento da batateira e absorcao de macronutrients influenciadospelossistemas de prepare de solo e irrigacao. In Pesquisa Agropecuaria Brasileira, vol. 41, 2006, no. 12, pp. 1787-1792.

OZTURK, G. - YILDIRIM, Z. 2014. Heritability estimates of some quantitative traits in potatoes. In Turkish Journal of Field Crops, vol. 19, 2014, no. 2, pp. 262-267.

PUSHKARNATH. 1976. Potato in Subtropics. New Delhi : Orient Longman, 1976, $289 \mathrm{p}$.

REGASSA, D. - BASAVARAJ, N. 2005. Genetic variability studies in potato (Solanum tuberosum L.). In Karnataka Journal of Agricultural Science, vol. 18, 2005, no. 1, pp. 87-90.

REINHARDT, D. - KUHLEMEIER, C. 2002. Plant architecture. In EMBO Report, vol. 3, 2002, pp. 846-851.

ROSS, H.A. - DAVIES, H.V. - BURCH, L.R. - VIOLA, R. - MCRAE, D. 1994 Developmental changes in carbohydrate content and sucrose degrading enzymes in tuberising stolons of potato (Solanum tuberosum). In Physiology Plantarum, vol. 90, 1994, pp. 748-756.

REINHARDT, D. - KUHLEMEIER, C. 2002. Plant architecture. In EMBO reports, vol. 3, 2002, no. 9, pp. 846-851.

SANANSE, S.L. - BORUDE, S.G. - PATIL, H.N. 1990. A study on variability and trends in area, production and productivity of rice in Konkan region of Maharashtra. In Journal of Maharashtra Agricultural University, vol. 15, 1990, no. 1, pp. 86-89.

SAXENA, R. - MATHUR, P. 2013. Analysis of potato production Performance and yield variability in India. In Potato J, vol. 40, 2013, no. 1, pp. 38-44.

SCHITTENHELM, S. - SOURELL, H. - LÖPMEIER, F.J. 2006. Drought resistance of potato cultivars with contrasting canopy architecture. In European Journal of Agronomy, vol. 24, 2006, pp. 193-202.

SCHUSTER, W.H. 1997. How much does plant breeding contribute to yield improvement of crops? In German Journal of Agronomy, vol. 1, 1997, pp. 9-18.

SCOFFONI, C. - RAWLS, M. - MCKOWN, A. - COCHARD, H. - SACK L. 2011. Decline of leaf hydraulic conductance with dehydration: Relationship to leaf size and venation architecture. In Plant Physiology, vol. 156, 2011, pp. 832-843. 
SCOTT, G.J. - SUAREZ, V. 2011. Growth rates for potato in India and their implications for industry. In Potato Journal, vol. 38, 2011, no. 2, pp. 100-12.

SINGH, B. - EZEKIEL, R. 2003. Influence of relative humidity on weight loss in potato tubers stored at high temperature. In Indian Journal of Plant Physiology, vol. 8, 2003, no. 2, pp. 141-144.

SHAHNAZARI, A. - AHMADI, S.H. - LAERKE, P.E. - LIU, F. - PLAUBORG, F. - JACOBSEN, S.E. - JENSEN, C.R. - ANDERSEN, M.N. 2008. Nitrogen dynamics in the soil-plant system under deficit and partial rootzone drying irrigation strategies in potatoes. In European Journal of Agronomy, vol. 25, 2008, pp. 65-73.

SINCLAIR, T.R. - MUCHOW, R.C. 1999. Radiation use efficiency. In Advances in Agronomy, vol. 65, 1999, pp. 215-265.

SPIELMEYER, W. - ELLIS, M.H. - CHANDLER, P.M. 2002. Semidwarf $(s d-1)$, 'green revolution' rice, contains a defective gibberellin 20-oxidase gene. In Proceedings of National Acadomy of Science USA, vol. 99, 2002, pp. 9043-9048.

SPITTERS, C.J.T. - SCHAPENDONK, A.H.C.M. 1990. Evaluation of breeding strategies for drought tolerance in potato by means of crop growth simulation. In Plant and Soil, vol. 123, 1990, pp. 193-203.

STARK, J.C. - PAVEK, J.J. - MCCANN, I.R. 1991. Using canopy temperature measurements to evaluate drought tolerance of potato genotypes. In Journal of American Society of Horticultural Science, vol. 116, 1991, pp. 412-415.

STREET, K. - HAMILTON, R.S. - TAY, D. - TABA, S. - MACKAY, M. 2009. Mining germplasm banks for photosynthetic improvement-wheat, rice, potato, legumes and maize. In Applying photosynthesis research to improvement of food crops. (eds.) Gready, Jill E. Dwyer, Simon A. - Evans, John R. Proceedings of a workshop held at the Australian National University, Canberra, Australian Capital Territory, Australia, 2-4 September 2009, pp. 112-129.

TREHAN, S.P. - SINGH, B.P. 2013. Nutrient efficiency of different crop species and potato varieties in Retrospect and prospect. In Potato Journal, vol. 40, 2013, no. 1, pp. 1-21.

VINCENTE, M.H. - ZSÖGÖN, A. - LOPODESÁ, A.F. - RIBEIRO, R.V. PERES, L.E.E.P. 2015. Semi-determinate growth habit adjusts the vegetative-to-reproductive balance and increases productivity and water-use efficiency in tomato (Solanum lycopersicum). In Journal of Plant Physiology, vol. 177, 2015, pp. 11-19.
VOS, J. - GROENWOLD, J. 1988. Mean annual yield reductions of potatoes due to water deficits for Dutch weather conditions. In Acta Horticulturae, vol. 214, 1988, pp. 61-70.

VOS, J. - HAVERKORT, A.J. 2007. Water availability and potato crop performance. In Potato biology and biotechnology: Advances and perspectives. ed. Vreugdenhil, D. - Bradshaw, J. - GEBHARDT, C. - GOVERS, F. - TAYLOR, M. A. - MACKERRON, D.K.L. - ROSS, H. A. Amsterdam : Elsevier, 2007, pp. 333-351.

VOS, J. - OYARZUN, P.J. 1987. Photosynthesis and stomatal conductance of potato leaves - effects of leaf age, irradiance and leaf water potential. In Photosynthesis Research, vol. 11, 1987, pp. 253-264.

VOSE, J.M. - RYAN, M.G. 2002. Seasonal respiration of foliage, fine roots, and woody tissues in relation to growth, tissue $\mathrm{N}$, and photosynthesis. In Global Change Biology, vol. 8, 2002, pp. 182-193. WALL, G.W. - GARCIA, R.L. - KIMBALL, B.A. - HUNSAKER, D.J. PINTER, P.J. JR. - LONG, S.P. - OSBORNE, C.P. - HENDRIX, D.L. WECHSUNG, F. - WECHSUNG, G. - LEAVITT, S.W. - LAMORTE, R.L. IDSO, S.B. 2006. Interactive effects of elevated carbon dioxide and drought on wheat. In Agronomy Journal, vol. 98, 2006, pp. 354-381. WISHART, J.T.S. - GEORGE, L.K. - BROWN, J.A. - THOMPSON, G. RAMSAY, J.E. - BRADSHAW, P.J. - WHITE, P.J. - GREGORY. 2009. Variation in rooting habit of potatoes: potential for improving resource capture. In International Symposium "Root Research and Applications, RootRAP, Boku - Vienna, Austria, 2-4 September 2009, pp.1-4.

WINKLER, E. 1971. Potato cultivation in Tyrol. II. Photosynthetic efficiency and respiration in different potato varieties. In Potato Research, vol. 14, 1971, pp. 1-18.

YAN, H. - KANG, M. - DE REFFYE, P. - DINGKUHN, M. 2004.A dynamic, architectural plant model simulating resource-dependent growth. In Annals of Botany, vol. 93, 2004, pp. 591-602.

YOU, L. - ROSEGRANT, M.W. - WOOD, S. - SUN, D. 2009. Impact of growing season temperature on wheat productivity in China. In Agricultural Meteorology, vol. 149, 2009, pp. 1009-1014. 